\title{
IMPLEMENTASI MODEL GUIDED DISCOVERY DALAM MENINGKATKAN KEMAMPUAN PROBLEM POSING SERTA DAMPAKNYA TERHADAP KECEMASAN MATEMATIS
}

\author{
Vevi Hermawan \\ Universitas Pasundan \\ vevi_pmat@unpas.ac.id
}

\begin{abstract}
ABSTRAK
Penelitian ini dilakukan berdasarkan tuntutan pemerintah yang menginginkan kurikulum 2013 berjalan, tetapi tidak diikuti oleh para siswa yang masih pasif dalam pembelajaran serta rendahnya motivasi belajar siswa akan pelajaran matematika. Penelitian ini bertujuan untuk mengetahui peningkatan kemampuan problem posing dengan menggunakan model pembelajaran guided discovery dan mendeskripsikan kecemasan matematika siswa dengan menggunakan model pembelajaran guided discovery. Menurut metodenya, penelitian ini merupakan penelitian campuran menggunakan desain eksplanasi sekuensial. Populasi dan sampel yang diambil dalam penelitian ini adalah kelas VIII SMP (di Kota bandung) sebanyak 2 kelas. Instrumen yang digunakan dalam penelitian ini adalah tes kemampuan problem posing dan angket skala kecemasan. Tes yang digunakan berupa tes tipe uraian. Skala kecemasan matematika siswa berisikan pernyataan-pernyataan kecemasan siswa terhadap pelajaran matematika. Tes terlebih dahulu diujicobakan kepada 10 siswa kelas IX. Berdasarkan hasil uji coba tersebut didapat koefisien realibitasnya tinggi. Data yang diperoleh kemudian diolah dengan bantuan SPSS 21.0 For Windows. Kemudian dilanjutkan dengan pengujian normalitas, homogenitas dan kesamaan dua rata-rata dengan menggunakan uji-t. Berdasarkan hasil analisis data hasil penelitian diperoleh kesimpulan : (1) Penurunan kecemasan matematika siswa kelas eksperimen tidak lebih baik atau sama dengan kelas kontrol. (2) peningkatan kemampuan problem posing kelas eksperimen tidak lebih baik atau sama dengan kelas kontrol. (3) terdapat perbedaan yang signifikan antara kemampuan kelas eksperimen dan kelas kontrol. (4) tidak ada korelasi antara penurunan kecemasan matematika dan kemampuan kognitif.
\end{abstract}

Kata Kunci : Guided Discovery, Kemampuan Problem Posing, dan Kecemasan Matematis.

\section{PENDAHULUAN}

Latar belakang penelitian ini yang pertama adalah daya saing sumber daya manusia yang semakin tinggi menjadi tuntutan pemerintah untuk meningkatkan kualitas SDM di negaranya yang tercantum pada tuntutan kurikulum 2013. Kemudian yang kedua fakta di lapangan yang terlihat bahwa dari skor rata-rata hasil ulangan semester I pokok bahasan persamaan kuadrat yaitu 59,67. Fakta di lapangan ini masih jauh dari harapan yang ada di kurikulum 2013 saat ini. dan yang ketiga adalah masih banyaknya siswa SMP yang masih takut dan merasa cemas dalam mempelajari mata pelajaran matematika dan terakhir adalah masih banyaknya tenaga pendidik mata pelajaran matematika yang kurang berkreasi dalam mengembangkan model pembelajaran yang menyenangkan. 
Rumusan masalah penelitian ini adalah : (1) Apakah penurunan positif tingkat kecemasan matematika siswa yang belajar dengan model Guided Discovery lebih baik daripada siswa yang belajar dengan pembelajaran konvensional ? (2) Apakah peningkatan kemampuan problem posing siswa yang belajar dengan model Guided Discovery lebih baik daripada siswa yang belajar dengan pembelajaran konvensional ? (3) Apakah terdapat perbedaan yang signifikan terhadap kemampuan problem posing siswa yang belajar dengan Guided Discovery dengan siswa yang belajar dengan pembelajaran konvensional ? (4) Apakah terdapat hubungan antara penurunan kecemasan matematika siswa dengan peningkatan kemampuan problem posing siswa terhadap model pembelajaran Guided Discovery?

\section{METODE PENELITIAN}

Metode penelitian yang akan digunakan dalam penelitian ini merupakan metode Campuran (Mixed Method).Dengan desain penelitian tipe Ekplanasi Sekuensial (The Explanatory Sequential Design). Berikut adalah desain Ekpanasi Sekuensial (Indrawan dan Yaniawati, 2014:82). Populasi dan sampel penelitian diambil dari 2 kelas VIII SMP (di Kota Bandung). Instrumen yang digunakan dalam penelitian ini adalah tes dan non tes. Tesnya adalah tes tipe uraian. Soal-soal untuk pretes dan untuk postes sama. Instrumen non tes yang digunakan adalah angket model skala kecemasan. Non tes berupa skala kecemasan menggunakan model Likert. Setelah semua data yang diperlukan telah terkumpul, dilanjutkan dengan pengolahan data tersebut sebagai bahan untuk menjawab permasalahan yang ada dalam penelitian.

\section{HASIL DAN PEMBAHASAN}

Berdasarkan hasil penelitian diperoleh bahwa kemampuan tes awal matematika siswa dalam materi persamaan kuadrat tidak berbeda secara signifikan, hal ini menunjukkan bahwa kemampuan problem posing siswa kelas eksperimen dan kelas kontrol pada saat sebelum penelitian hampir memiliki kemampuan yang sama. Setelah dilakukan pembelajaran menggunakan model pembelajaran guided discovery pada kelas eksperimen dan model pembelajaran pada kelas konvensional diperoleh hasil bahwa kemampuan problem posing siswa memiliki perbedaan yang signifikan. Hal ini membuktikan bahwa dengan adanya model pembelajaran yang berbeda memberi pengaruh terhadap kemampuan matematika siswa.

Berdasarkan hasil penelitian pada peningkatan kemampuan problem posing siswa didapat peningkatan kelas eksperimen berada di kategori rendah begitupun dengan peningkatan 
kelas kontrol berada di kategori rendah. Oleh karena itu, hasil uji hipotesis didapat bahwa peningkatan kemampuan problem posing siswa kelas eksperimen tidak lebih baik atau sama dengan peningkatan kemampuan problem posing siswa kelas kontrol. Mengapa terjadi demikian? Berdasarkan hasil observasi dan wawancara peneliti selama pembelajaran berlangsung, hal ini disebabkan pertama karena siswa tidak dibiasakan oleh orang tua dan guru sewaktu sekolah dasar untuk bertanya terlebih dahulu mengenai pembelajaran. Mereka merasa takut jika sebelum memulai pembelajaran mereka bertanya terlebih kepada kepada gurunya. Yang kedua, siswa bingung untuk bertanya materi yang mereka sendiri belum pernah mempelajari, Mereka terbiasa oleh gurunya langsung menyelesaikan suatu permasalahan tanpa mengetahui permasalahannya timbul dari mana. Karena faktor-faktor di atas maka peneliti menyimpulkan bahwa mengapa hasil penelitian untuk peningkatan kemampuan problem posing siswa itu berada di kategori rendah.

Berdasarkan hasil angket skala kecemasan matematika siswa, didapat bahwa penurunan kecemasan matematika siswa kelas eksperimen berada pada rata-rata 2,649 dan penurunan kecemasan matematika siswa kelas kontrol berada pada rata-rata 2,804. Berdasarkan kriteria penurunan kecemasan matematika kedua kelas ini berada di kategori cukup. Hasil analisis data dan uji hipotesis didapat bahwa penurunan positif kecemasan matematika siswa kelas eksperimen tidak lebih baik atau sama dengan penurunan positif kecemasan matematika siswa kelas kontrol. Hal ini bisa disebabkan oleh siswa yang kemampuan kognitifnya meningkat pada kelas eksperimen masih merasa cemas atau gelisah bila menghadapi pelajaran matematika maupun ulangan matematika. Hal ini didukung oleh wawancara beberapa siswa kelas eksperimen yang mengatakan bahwa walaupun mereka sudah bisa dalam menyelesaikan masalah matematika mereka masih kurang percaya diri bila mereka mengerjakannya secara individu. Maka mereka masih merasa cemas bila harus menghadapi pelajaran yang mereka anggap sulit seperti pelajaran matematika.

Berdasarkan hasil uji korelasi antara penurunan kecemasan matematika dan peningkatan kemampuan problem posing siswa yang mendapatkan model pembelajaran konvensional didapat bahwa tidak ada korelasi antara penurunan kecemasan matematika dan peningkatan kemampuan problem posing. Hal ini dibuktikan oleh tingkat korelasi yang berada pada nilai 0,272 yang artinya korelasi rendah. Faktor lainnya seperti yang sudah dikatakan sebelumnya 
bahwa walaupun kemampuan kognitifnya meningkat tidak mengubah persepsi siswa akan pelajaran matematika yang selalu membuat mereka merasa cemas.

\section{KESIMPULAN}

Berdasarkan hasil penelitian dan analisis data serta pengujian hipotesis dalam penelitian ini, sebagaimana telah dibahas pada bab sebelumnya, maka kesimpulan yang dapat diambil adalah sebagai berikut 1) Penurunan positif tingkat kecemasan matematika siswa kelas eksperimen tidak lebih baik atau sama dengan penurunan positif tingkat kecemasan matematika siswa kelas kontrol. 2) Peningkatan kemampuan problem posing siswa kelas eksperimen tidak lebih baik atau sama dengan peningkatan kemampuan problem posing siswa kelas kontrol. 3) Terdapat perbedaan yang signifikan terhadap kemampuan problem posing dan kemampuan pemecahan masalah matematika siswa yang belajar dengan model pembelajaran guided discovery dengan siswa yang belajar dengan pembelajaran konvensional. 4) Tidak terdapat korelasi (korelasi rendah) antara penurunan kecemasan matematika siswa dengan peningkatan kemampuan problem posing siswa terhadap model pembelajarn guided discovery.

\section{REFERENSI}

Abdurrahman, M. (2003). Pendidikan Bagi Anak Berkesulitan Belajar. Jakarta: PT. Rineka Cipta dan Departemen Pendidikan dan Kebudayaan.

Anita, Ika W. (2014). Pengaruh Kecemasan Matematika (Mathematics Anxiety) Terhadap Kemampuan Koneksi Matematis Siswa SMP. [online]. Tersedia : ejournal.stkipsiliwangi.ac.id/index.php/infinity/article/view/43/42+\&cd=1\&hl=id\&ct=cln k\&gl=di. Diakses 20 April 2016.

Elwan A, Reda. (2002). Effectiveness Of Problem Posing Strategies On Prospective Mathematics Teachers' Problem Solving Performance. [online]. Tersedia : http://www. recsam.edu.my/R\&D_Journals/YEAR2002/2002Vol 25No1/56-69.pdf. Diakses 20 April 2016.

Hake, R,R. (1999). Analyzing Change / Gain Scores. [online]. Tersedia: http://www.physics. indiana.edu/ sdi/AnalyzingChange-Gain.pdf. Diakses 15 Juni 2013.

Handayani, D. B. (2008). Efektivitas Penerapan Metode Problem Posing Dan Tugas Terstruktur Terhadap Prestasi Belajar Siswa. [online]. Tersedia : http://forumkependidik 
an.unsri.ac.id/userfiles/Artikel\%20Bestari\%20DH-UNNES(3).pdf. Diakses 20 April 2016.

Indrawan, R. dan Yaniawati, P.(2014). Metodologi Penelitian. Bandung: PT Refika Aditama. Iskandar. (2004). Strategi Pembelajaran Konstruktivistik dalam Kimia. Malang: Semi-Qui V Jurusan Kimia FMIPA UM.

Johnrival, P.S. (2015). Pengaruh Pembelajaran Penemuan Terbimbing terhadap Kemampuan Koneksi Matematis dan Kecemasan Matematis Siswa Kelas VII. Tesis FPs UPI. Bandung: Tidak Diterbitkan.

Kemendikbud. (2013). Permendikbud No.81A tentang Implementasi Kurikulum. Jakarta: Kementrian Pendidikan dan Kebudayaan.

Muslich, M. (2007). KTSP Pembelajaran Berbasis Kompetensi dan Kontekstual. Jakarta: Bumi Aksara.

Nurcahyo, N. (2014). Pendekatan Problem Posing untuk Meningkatkan Kemampuan Pemecahan Masalah dan Pengajuan Masalah Matematis serta Habits of Mind Siswa SMA. Tesis FPs UPI. Bandung: Tidak Diterbitkan.

Ruseffendi, E.T. (2005). Dasar-Dasar Penelitian Pendidikan dan Bidang Non-Eksakta Lainnya. Bandung: Tarsito.

Slameto. (2003). Belajar dan Faktor-Faktor yang Mempengaruhinya. Jakarta: PT Rineka Cipta. Suherman, E dan Sukjaya, Y. (1990). Evaluasi Pendidikan Matematika. Bandung: Wijayakusumah.

Uyanto, S,S. (2009). Pedoman Analisis Data dengan SPSS. Yogyakarta: Graha Ilmu.

Wahyuningtyas, F. (2015). Keefektifan Model Guided Discovery Learning Berbasis Multiple Intelligences terhadap Kemampuan Pemecahan Masalah. Tesis FPs UNNES. Semarang: Tidak Diterbitkan.

Zaini, A. (2014). Pembelajaran Problem Posing. [online].Tersedia: https://mathspenlaz.com/2014/08/06/problem-posing-belajar-dari-masalah-membuatmasalah/. Diakses 7 April 2016 